<原 著 $>$

広沉肝切除時における網内系賦活の意義に関する実験的研究

\begin{tabular}{|c|c|}
\hline 利 & 大和田康夫 \\
\hline 木 正德 & 富永 \\
\hline
\end{tabular}

要 旨：広沉肝切除時における網内系賦活の意義を明らかにするため,ラットに打いて OK432 にる賦活後, $70 \%$ 肝切除を行い各種検討を行った。 その結果，血中エンドトキシン值や， GOT, GPT は肝切除12時間後それぞれ $14.7 \pm 7.5 \mathrm{pg} / \mathrm{m} l, 633 \pm 75 \mathrm{U} / \mathrm{L}, 833 \pm 225 \mathrm{U} / \mathrm{L}$ と最高 值を示したが，OK-432投与により $2.8 \pm 0.7 \mathrm{pg} / \mathrm{m} l, 442 \pm 142 \mathrm{U} / \mathrm{L}, 258 \pm 91 \mathrm{U} / \mathrm{L}$ と增加は有意 に抑制された。血清補体価 $\mathrm{CH}_{50}$ は肝切除12時間後 $36.5 \pm 9.4 \mathrm{U} / \mathrm{m} l$ と低下したが, OK-432投与 により $61.5 \pm 15.2 \mathrm{U} / \mathrm{m} l$ と有意に改善された。一方, 肝ミトュンドリアの ATP 生成能, および 肝での RNA，DNA 合成能は OK-432投与によりさらに六進したが，非投与群との間に有意差 は生じなかった，RNA 量においては，非投与群と比し有意の増加を認めた。.以上より，広汎肝 切除時に網内系を賦活すると，エンドトキシン処理能が六進し，その結果肝機能障害の軽減や 術後の低補体価傾向の改善を認めた。ささらに，残存肝のエネルギー代謝や蛋白合成能が促進さ れることが示唆された。

索引用語： 広沉肝切除 網内系賦活 エンドトキシン 術後肝機能障害

広沉にわたる肝切除術は侵襲が大きく，術後に肝不 全, 腎不全, 呼吸不全, 消化管出血などの multiple organ failure (MOF) を併発し易い。これら合併症の 発症機序として，網内系機能低下によるェンドトキシ ンを始めとした微小異物の処理能低下が指摘されてい る1)。そこで著者らは，ラットに打いて OK-432による 網内系機能賦活後，70\%肝切除を行い，血中ェンドト キシン值, 各種肝機能, 血清補体価 $\mathrm{CH}_{50}$, 肝エネル ギー代謝, 肝再生などの面から，広沉肝切除時におけ る網内系機能賦活の意義について検討した。

\section{実験材料および方法}

体重200 250gの SD系雄性 ラットを実験に用い た. 実験群を，網内系機能を賦活した OK-432投与群 と, 賦活しないOK-432非投与群の 2 群とし, ェーテル 麻醉下に Higgins-Anderson ${ }^{2}$ Kよる70\%肝切除後，各 種検討を行った。な打網内系機能の賦活は，肝切除 48 時間前および24時間前に，OK-432(中外製薬)を $25 \mathrm{KE}$ ずつ生理的食塩水 $2 \mathrm{~m} l$ に溶解し，腹腔内に投与する方 法によった。

1）網内系機能測定

*東北大学医学部第 1 外科

＜受付日62年 6 月29日 $>$
単開腹または肝切除24時間後に，太田らの方法采に 従って網内系機能を測定した。すすなわら ${ }^{59} \mathrm{Fe}$ 標識コン ドロイチン硫酸鉄（比放射能 $8.4 \mu \mathrm{ci} / \mathrm{Fe} 4 \mathrm{mg} /$ コンドロ イチン硫酸ソーダ $20 \mathrm{mg} / \mathrm{m} l$ ) を体重 $1 \mathrm{~kg}$ 当たり $0.5 \mathrm{~m} l$ を陰茎静脈より速やかに注入乙, 注入前, 注入後 5 分， 20 分に股動脈より各 $0.1 \mathrm{~m} l$ 採血し，Scintillation counter にてその放射活性を測定した，領食指数 $\mathrm{K}$ 值 は, Halpern ら

$\mathrm{K}=\frac{\log \mathrm{C}_{1}-\log \mathrm{C}_{2}}{\mathrm{~T}_{2}-\mathrm{T}_{1}}$

$\mathrm{C}_{1}=\mathrm{T}_{1}$ 時に劣ける全血 $0.1 \mathrm{~m} l$ 当たりの放射活性 (cpm)

$\mathrm{C}_{2}=\mathrm{T}_{2}$ 時に括ける全血 $0.1 \mathrm{~m} l$ 当たりの放射活性 (cpm)

${ }^{59} \mathrm{Fe}$ 標識コンドロイチン硫酸鉄の注入20分後, 生体 灌流卓を行ってから, 肝脾肺の Homogenate 作成 し, その放射活性を測定して各臓器別の ${ }^{59} \mathrm{Fe}$ 摄取率を 算定した。

2）血中ェンドトキシンの測定

肝切除直前および術後 $12 ， 24 ， 36 ， 48$ 時間を経て． 各群ラットをェーテル麻醉下に開胸し，心穿刺により 無菌的にへパリン採血した。次に血液を $150 \times \mathrm{G}$ にて10 分間冷却遠心後, 多血小板血墏を取り出し過塩素酸に 
て前処理後, 合成基質法 ${ }^{6)}$ (トキシカラーテスト(B) 用いてェンドトキシンを定量した。

3）各種肝機能，血清補体価の測定

前項と同様に, 各群ラットより経時的に採血し, 各 種肝機能，血清補体価 $\mathrm{CH}_{50}$ を測定した。肝機能は， GOT, GPT Reitman-Frankel一百瀬変法にて, LDH 定は Mayer の50\%溶血単位測定法”) 亿従った。

4）肝ミトコンドリア呼吸能の湘定

前項と同じラットの肝を採取し, HogeboomSchneider の方法衫に準じてミトコンドリフ画分を分 離調整し、コハク酸を呼吸基質として用い，溶存酸素 濃度記録計 (Gilson 社, Model 5/6H, Oxygraph) に て呼吸曲線を記録した。これより萩原の報告に潐拠し た方法")で, State 3 の酸素消費量と酸化的リン酸化能 (P/O) を求め，ATP 生成能を算定した。

5）肝 RNA およびDNA 合成能，量の測定

肝切除後 $11 ， 23 ， 35 ， 47$ 時間を経て，各群ラットに ${ }^{3} \mathrm{H}$-orotic acid $(20 \mu \mathrm{ci} / 100 \mathrm{~g})$ を腹腔内投与し， 1 時間 後に肝を採取して, Schmidt-Thannhauser-Schneider 法10)に準じてRNA 括よび DNAを抽出した. RNA， DNA の放射活性より比活性を算定してそれぞれの合 成能とし，また RNA はオルシノール法で, DNAはジ フェニールアミン法で定量した。

検査成績は平均土標準偏差で示し，有意差検定は Student's $\mathrm{t}$ test を用いた。

\section{1）網内系機能}

\section{成 績}

OK-432非投与群の食食指数 $\mathrm{K}$ 值は，70\%肝切除它 より約1/2k低下した (Fig. 1)。一方，OK-432投与に より網内系機能は著明に賦活され，単開腹では $\mathrm{K}$ 值は 非投与群の1.6倍と著明に増加したが, 肝切除24時間後

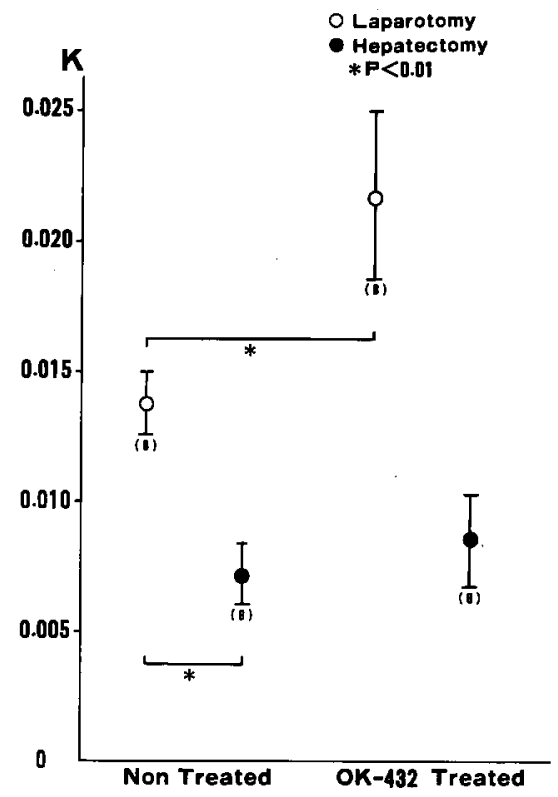

Fig. 1 Phagocytic index $\mathrm{K}$ after laparotomy and $70 \%$ hepatectomy.

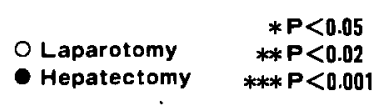

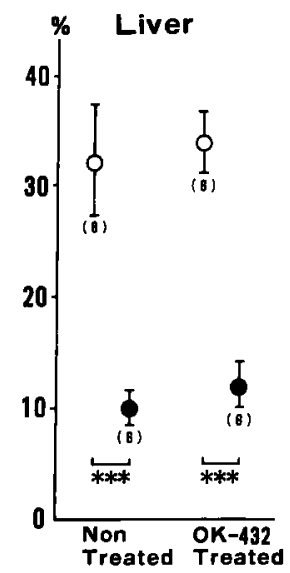
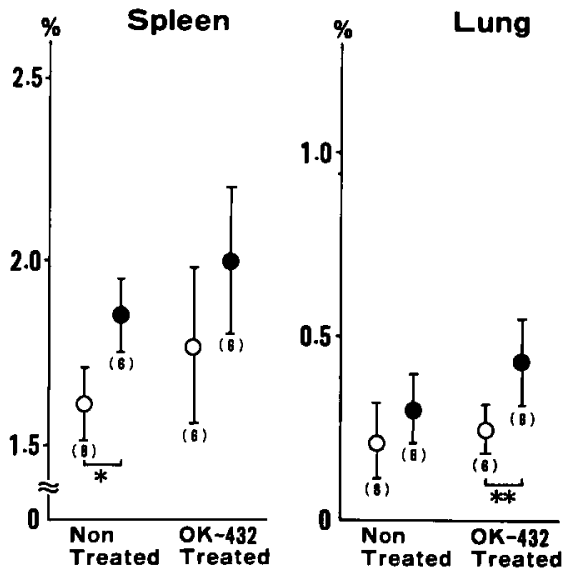

Fig. $2{ }^{59} \mathrm{Fe}$ uptake in the liver, spleen and lung after laparotomy and $70 \%$ hepatectomy. 


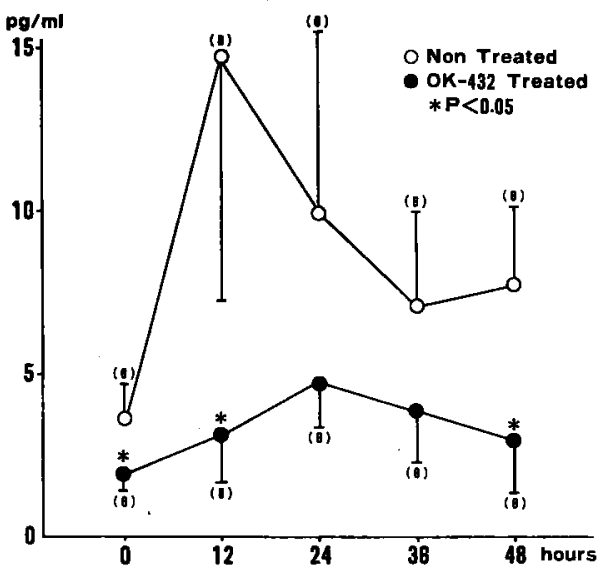

Fig. 3 Changes of endotoxin levels after $70 \%$ hepatectomy.
においては非投与群の1.2倍にしか増加しなかった。

臟器別 ${ }^{59} \mathrm{Fe}$ 摂取率は Fig. 2 のごとくで，OK-432非 投与群の単開腹では，肝の ${ }^{59} \mathrm{Fe}$ 撕取率が32.20士 5.31\%であるのに対し，脾肺での摄取率はそれぞれ $1.61 \pm 0.09 \% ， 0.21 \pm 0.10 \%$ と極めて低かった。 $70 \%$ 肝切除後, 肝での摂取率は $10.02 \pm 1.67 \%$ 之著明に低下 したが，脾肺特に脾での有意な増加を認めた。一方， OK-432投与により ${ }^{59} \mathrm{Fe}$ 摄取率は肝脾肺いずれにおい ても非投与群を上回り，肝切除後においてる同様な傾 向がみられたが，両群間に有意差は生じなかった。

2）血中エンドトキシン值の推移

肝切除直前の血中エンドトキシン値は, OK-432非投 与群では $3.6 \pm 1.1 \mathrm{pg} / \mathrm{m} l$ と投与群の $1.9 \pm 0.6 \mathrm{pg} / \mathrm{m} l$ と比較し有意の高值を示した (Fig. 3). 肝切除後, 非 投与群では血中ェンドトキンン值は著明に増加し, 肝
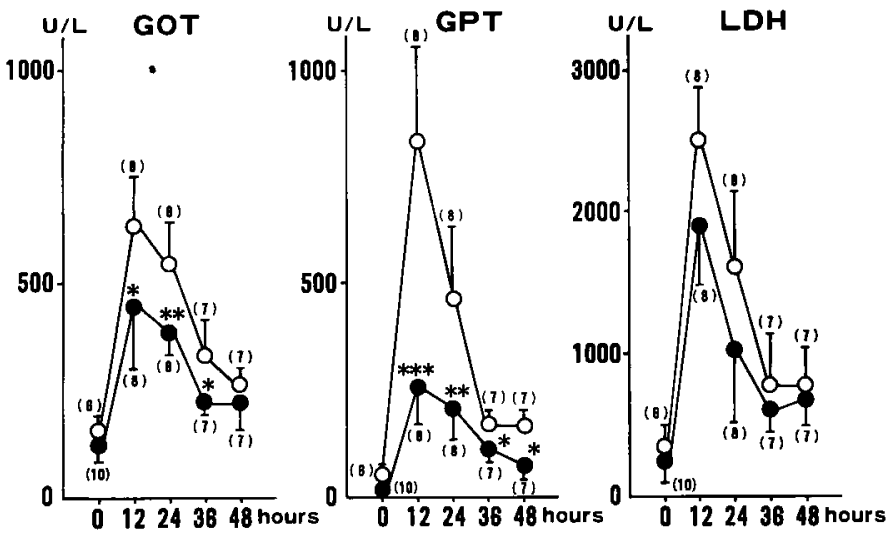

Fig. 4 Changes of GOT, GPT and LDH after 70\% hepatectomy.

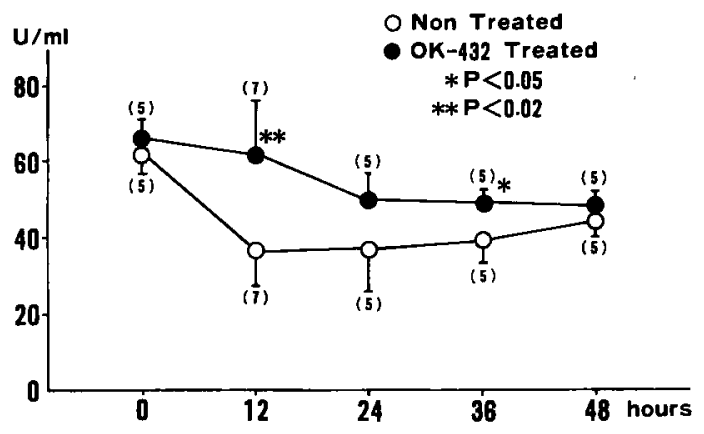

Fig. 5 Changes of the hemolytic activity of complement $\left(\mathrm{CH}_{50}\right)$ after $70 \%$ hepatectomy.
切除12時間後 $14.7 \pm 7.5 \mathrm{pg} / \mathrm{m} l$ と最高値をとり，その 後急激に減少したが，48時間後でも投与群の $2.9 \pm 1.5$ $\mathrm{pg} / \mathrm{m} l$ に対し $7.7 \pm 2.4 \mathrm{pg} / \mathrm{m} l$ と有意の高值を認めた. 一方, OK-432投与群では, 術後血中ェンドトキシン値 の増加は軽度で, 最高値を認めた24時間後でも $4.7 \pm$ $1.3 \mathrm{pg} / \mathrm{m} l$ と低値であった。

3）各種肝機能，血清補体価の推移

非投与群では肝切除後，GOT，GPT，LDH は著明

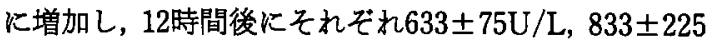

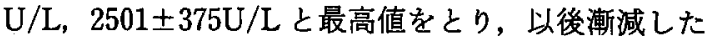
(Fig. 4). OK-432投与群においても同様の傾向を認め たが，増加の程度は軽く，特にGOT や GPT では非投 


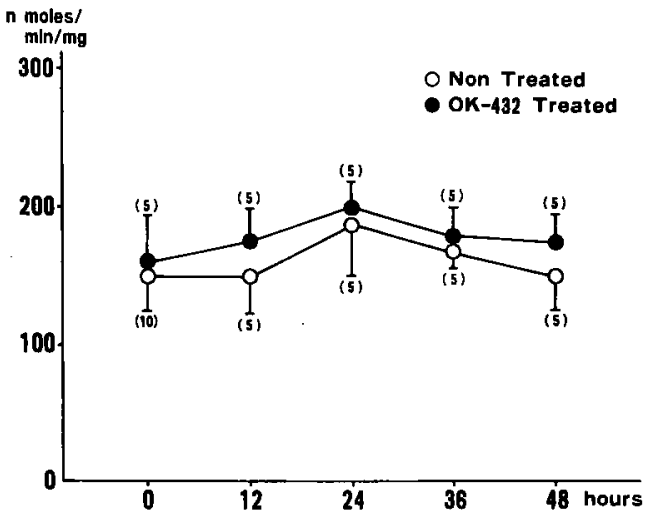

Fig. 6 Changes of ATP synthesis after $70 \%$ hepatectomy.
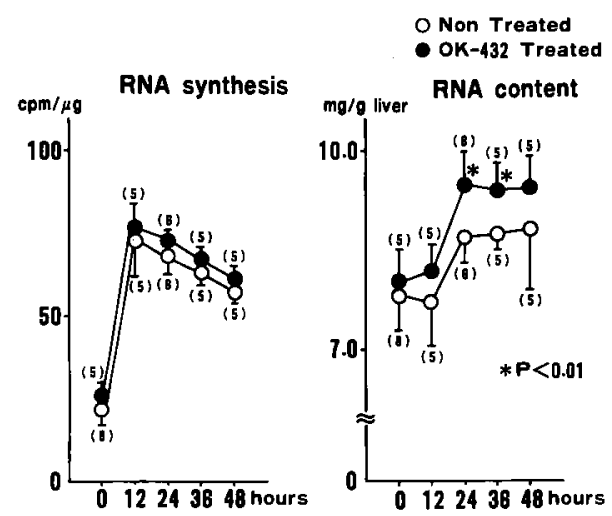

Fig. 7 Changes of RNA synthesis and content after $70 \%$ hepatectomy.

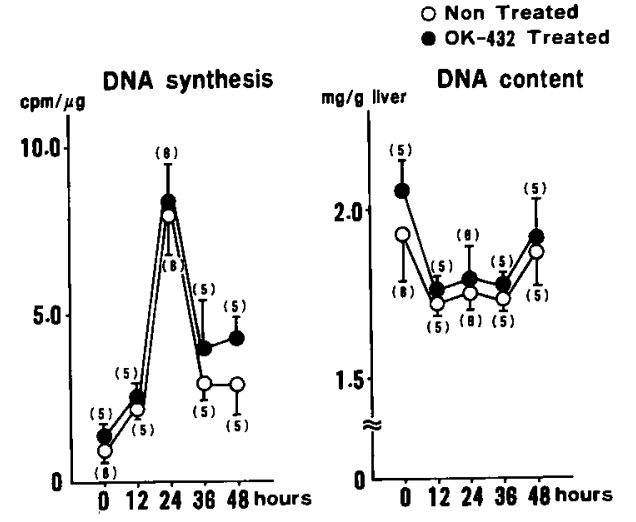

Fig. 8 Changes of DNA synthesis and content after $70 \%$ hepatectomy.
与群と比較し有意に上昇が抑制された。

血清補体価 $\mathrm{CH}_{50}$ は Fig. 5 のごとく，肝切除後低下 したが, OK-432投与によりこの低補体価㑯向は改善さ れた. 特に12時間後に打いては，非投与群の $36.5 \pm 9.4$ $\mathrm{U} / \mathrm{m} l$ に対し投与群は $61.5 \pm 15.2 \mathrm{U} / \mathrm{m} l$ と有意な高値 を示した。

4）肝ミトコンドリア呼吸能の推移

肝ミトコンドリフでの ATP 生成能は, 肝切除後立 進し, 24時間後に $186.3 \pm 36.3 \mathrm{n} \mathrm{moles} / \mathrm{min} / \mathrm{mg}$ 之最高 值を示した(Fig. 6). OK-432投与により, 肝切除後の ATP生成能はさらに亢進したが，非投与群との間に 有意差はみられなかった。

5）肝 RNA 括よび DNA 合成能，量の推移

肝切除後の肝 RNA 合成能括よび量の推移を Fig. 7 飞, 䀒 DNA の推移を Fig. 8 に示した. OK-432非投与 群での RNA 合成能は, 肝切除12時間後 $72.5 \pm 10.9$ $\mathrm{cpm} / \mu \mathrm{g}$ と著明に立進し，以後濑减した。 OK-432投与 により，RNA 合成能はさらにえ進したが，非投与群と の間に有意差はみられなかった。一方, RNA 量は肝切 除後次第に増加し，特に OK-432投与群では24おるひび 36時間後にそれぞれ $9.5 \pm 0.5 \mathrm{mg} / \mathrm{g}$ liver, $9.4 \pm 0.4$ $\mathrm{mg} / \mathrm{g}$ liver と, 非投与群の $8.6 \pm 0.3 \mathrm{mg} / \mathrm{g}$ liver, $8.7 \pm$ $0.2 \mathrm{mg} / \mathrm{g}$ liver に比し有意の増加がみられた.

DNA 合成能は, 肝切除 24 時間後に $7.9 \pm 1.2 \mathrm{cpm} / \mu \mathrm{g}$ と最大值を示し，その後漸減した。 OK-432投与により， DNA 合成能はさらに六進したが，非投与群との間に 有意差は認めなかった。

DNA 量は肝切除後減少したが，48時間後には回復 がみられた，DNA 量においても，OK-432投与群は非 投与群より常に高値を示したが，両群間に有意差はみ られなかった。

\section{考 察}

肝切除を契機として特有の合併症が高頻度に発生し 易く, 特に肝硬変例ではその傾向が著明で, 術後管理 に難治することが多い11,12)．そのためいきおい肝切除 には慎重にならざるを得ず，肝癌症例に対し肝動脈栓 塞療法や経皮経肝的エタノール注入などの非手術療法 がしばしば行われているのが現状である。この肝切除 時注じるMOFの発生機序としては，全身の網内系 貪食作用の低下，特に肝 Kupffer 細胞の機能低下が指 摘されている1)。すなわち, エンドトキシンを始めとす る，細菌，抗原，その他代謝産物などあらゆる毒性物 質を処理する網内系機能の低下のため, 敗血症, 肝不 全, 腎不全などの MOF が生じると考えられている.最 
近，血中のこれら微小異物を除去する目的で，血嶈交 換が行われるようになってきたが，大量の血墏を必要 とし，またその臨床効果にす限界がみられる ${ }^{13)}$.そこで 著者らは, 生体に本来備わっている異物処理機構であ る網内系機能に着目し，ラットに扣いて網内系機能を 賦活し，肝切除への影響についての検討を行った。

網内系機能の賦活剤としては，容易に入手できまた 安全に臨床応用できる薬剤として, OK-432を選択し た. 本剤は Streptococcus hemolytics Su 株をぺニシ リン G の共存下に一定条件で処理し, 凍結乾燥した菌 体製剤で，現在免疫賦活郕として癌症例に広く利用さ れている。OK-432は単に免疫能ばかりでなく，網内系 機能をす強力に賦活する作用があり，著者らは実験 的・臨床的にこの作用を確認している ${ }^{14)}$. 本実験に打い ても，OK-432 投与により肝脾肺での ${ }^{59} \mathrm{Fe}$ 摄取率は増 大し，貪食指数 $\mathrm{K}$ 值は有意に増加した。

内因性エンドトキシンは，腸内細菌に由来し，主に 肝の Kupffer 細胞によって血中より除去される。しか し，広沉肝切除などにより網内系機能が著明に低下し ている場合には，肝で処理しきれないエンドトキシン は全身に循環し, 種々の臓器に影響を及ぼし, MOFを 発症するとされている15,16). 事実本実験においても， OK-432非投与群では汗切除後血中エンドトキシン值 は著明な増加を認めた。一方, OK-432にて網内系機能 を賦活した群では，血中ェンドトキシン值の増加は軽 度であった．すなわち広汎肝切除時に積函的に網内系 機能を賦活することは，エンドトキシンを始めとする 毒性物質の処理能を高め，合併症発症を抑制する可能 性が示唆された。

GOTやLDH などの血清醭素は, 肝細胞壊死あるい は肝細胞膜透過性亢進などの肝障害の結果, 血中に出 現すると考元られている ${ }^{17}$. 肝切除後の GOT や GPT の増加が OK-432により有意に抑制された機序として は，網内系機能賦活によりエンドトキシンを始めとし た毒性物質が減少し，その結果肝障害が抑制されたも の之推察された，しかし，血清酵素を処理するのは網 内系細胞であり，GOT ゃGPT の有意の低下はこの処 理能の改善によるところも多いと思われる。

補体成分の産生藏器は肝臟であり，広沉な肝切除に より血清補体価 $\mathrm{CH}_{50}$ は著明に減少した。 また補体価 の低下は免疫複合体による補体の活性化，消費の増大 によってもたらされることも知られている18). 本実験 では，肝切除後の低補体価傾向は OK-432投与により 有意に改善されており，補体の活性化や消費の増大が
抑制されたものと思われる.

肝切除後, 残存肝の再生に必要な核酸や蛋白の合成 のために膨大なエネルギーを必要とし，その多くは肝 ミトコンドリアの乎吸により生成されるATPにより 供給されている19)。このエネルギーを補給するために は，肝ミトコンドリアのATP 生成能の亢進が必須で あり，本実験に扔いてもその傾向を認めた，特に OK432投与群では，ATP 生成能の促進傾向がより著しく 認められた。 また肝切除後, 残存肝のエネルギー代謝 の亢進に続いて，核酸合成の充進が生じる も, 肝切除後 RNA や DNA 合成能は著明に増加し, RNA 量も次第に増加し，特に OK-432投与群でその傾 向は著しかった。

以上述べたごとく,ラットの広沉肝切除時において， OK-432投与により残存肝でのエンドトキンンを始め とする微小異物の処理能は著明に亢進し，術後の低補 体価傾向の改善を認めた。さらに残存肝での肝機能障 害の軽减, エネルギー代謝の促進や肝蛋白代謝の改善 がみられた．以上の結果より，OK-432投与による網内 系機能倵活は，肝切除後の合併症発症を予防し，さら に残存肝の再生に対し有利に働くことが示唆された。

\section{まとめ}

広沉肝妡除時における網内采機能倵活の意義を明ら かにする目的でラットに扎いてOK-432による網内 系機能倵活後 $70 \%$ 肝切除を行い以下の結果を得た。

1）血中エンドトキンン值は, 肝切除後急激に增加し たが，OK-432投与により増加は有意に抑制された。

2）肝切除後著明に增加した GOT や GPT は，OK432投与により有意に抑制された。

3）肝切除後にみられる低補体価傾向は，OK-432投 与により有意に改善された。

4）肝ミトコンドリアの ATP 生成能は, 肝切除後増 加したが，OK-432投与によりさらに六進する傾向がみ られた。

5）残存肝の RNA 括よび DNA 合成能は，OK-432 によりさらに増加する傾向にあり，肝 RNA 量も非投 与群と比較し有意の増加がみられた。

稿を終えるにあたり、エンドトキシンの測定をおこなっ ていたたいた東北大学第 3 内科矢島義昭先生に深謝致しま す.

\section{文献}

1）横田峻，河野幸裕, 奈良正信, 他: 肝手術之肝網 内系。日消外会誌 $13 ： 933-938 ， 1980$ 
2) Higgins GM, Anderson RM: Experimental pathology of the liver. Arch Path 12 : 186-202, 1931

3）太田太郎：コンドロイチン硫酸鉄を用いる網内系 機能検查法. 大阪大学医学雑誌 $21: 147-170$, 1969

4) Halpern BW, Benacerraf B, Biozzi G: Quantitative study of the granulopoietic activity of the reticuloendothelial system. Brit J Exp Path $34: 426-440,1953$

5) Copp DH, Greenberg DM : A tracer study of iron metabolism with radioactive iron. J Biol Chem $164: 389-401,1946$

6) Iwanaga $S$, Morita $T$, Harada $T$, et al : Chromogenic substrates for horseshoe crab clotting enzyme. Haemostasis $7: 183-188,1978$

7) Mayer MM : Experimental immunochemistry. 2nd ED, edited by Kabat EA and Mayer MM, Charles C. Thomas, Springfield, Illinois, 1961, p133-140

8) Hogeboom GH, Schneider WC: Isolation of intact mitochondria from rat liver. J Biol Chem 172 : 619-635, 1948

9）小山研二, 伊藤賢司, 音羽 剛, 他：閉塞性黄疸肝 のミトコンドリア機能について。肝臓 $20: 579$ $-586,1979$

10) Schneider WC: Phosphorus compounds in animal tissues. J Biol Chem $164: 747-751,1946$

11）日本肝癌研究会：原発性肝癌に関する追跡調查.
肝臓 $23: 675-681,1982$

12) Iwatsuki S, Starzl TE: Experience with 150 liver resections. Ann Surg 197 : 247-253, 1983

13）松原修二, 岡部健二, 大内清昭, 他：肝不全に対す る血液交換法の効果之限界. 人工臟器 $16: 950$ -953, 1987

14）中川国利, 小山研二, 浅沼義博, 他：硬変肝切除時 における網内系賦活の意義に関する実験的研究. 肝葴 $26: 445-452,1985$

15) Nakagawa $K$, Matsubara $S$, Ouchi $K$, et al : Endotoxemia after abdominal surgery. Tohoku J Exp Med 150: 273-280, 1986

16）矢島義昭：合成発色基質を用いた血中ェンドトキ シン測定法の臨床応用之肝疾患に和けるェンドト キシン血症の臨床的意義について。肝藏 27 ： $934-944,1986$

17) Sekas G, Cook RT: The evaluation of liver function after partial hepatectomy in the rats. Br J Exp Path 60 : 447-452, 1979

18) Wyke RI, Rajkovic IA, Williams R : Defective opsonisation and complement deficiency in serum from patients with fulminant hepatic failure. Gut $21: 643-649,1980$

19）小涬和恵: 肝予備能の意義と判定. 外科治療 $47: 671-678,1982$

20) Hecht LI, Potter VR: Nucleic acid metabolism in regenerating rat liver. Cancer Research $16: 988-993,1956$

\title{
Significance of activation of reticuloendothelial system on hepatectomy
}

\author{
Kunitoshi Nakagawa, Yasuo Owada, Kiyoaki Ouchi, Masanori SuzukI, \\ Tsuyoshi Tominaga and Toshio Sato*
}

The prognosis of patients after massive hepatectomy is poor in certain cases whose hepatic reserve, including reticuloendothelial function, is deteriorated. We administered OK-432 before 70\% hepatectomy on rats to activate the reticuloendothelial system and studied its effect on postoperative course. The elevations in plasma endotoxin, GOT, and GPT were attenuated, and the deterioration of the complement activity after hepatectomy was greatly improved by OK-432 treatment. The RNA content in the liver was significantly increased by $\mathrm{OK}-432$ administration. These findings suggest that activation of the reticuloendothelial system at the time of massive hepatectomy enhances endotoxin clearance from blood and thereby contributes in lessening the magnitude of hepatic injury, maintaining the serum complement, and improving liver protein synthesis.

\footnotetext{
* First Department of Surgery, Tohoku University School of Medicine (Sendai)
} 